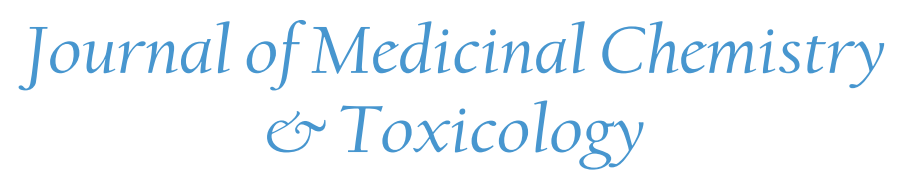

\title{
Antimicrobial Activity Studies from Poisonous Short Nosed Tripod Fish, Triacanthus biaculeatus (Bloch, 1786) from Visakhapatnam Coastal Waters, India
}

\author{
Jyothi, K², N.M. Krishna ${ }^{1 *}$, V. Govinda Rao ${ }^{1}$ and S.Geetha ${ }^{3}$ \\ ${ }^{1}$ Department of Marine Living Resources, College of Science and Technology, Andhra University, Visakhapatnam, Andhra \\ Pradesh, India \\ ${ }^{2}$ Department of Botany, College of Science and Technology, Andhra University, Visakhapatnam, Andhra Pradesh, India \\ ${ }^{3}$ Department of Microbiology, College of Science and Technology, Andhra University, Visakhapatnam, Andhra Pradesh, India
}

*Corresponding authors: N.M. Krishna, Department of Marine Living Resources, College of Science and Technology, Andhra University, Visakhapatnam - 530003, Andhra Pradesh, India; Tel: 9912991299; E-mail: krishna.muddu217@gmail.com

\begin{abstract}
An antimicrobial validatory screening of short nosed tripod fish Triacanthus biaculeatus (Bloch, 1786) collected from the Visakhapatnam coastal waters, India is done in such a way T. biaculeatus muscle extracts were subjected for antimicrobial assay. Antimicrobial screening assay was done in five bacterial pathogens viz., Escherichia coli (MTCC-443), Salmonella typhi (MTCC-421), Pseudomonas aeruginosa (MTCC2295), Vibrio cholera (MTCC-459) and Staphylococcus aureus (MTCC-3160) using the standard well diffusion method. The results confirmed a positive test against most of the pathogens used. Maximum antimicrobial effect against Vibrio cholera of $3.8 \mathrm{~mm}$ in diameter is reported. The present investigation has revealed that positive progresses in the fish (T. biaculeatus) muscle extracts against human pathogens.
\end{abstract}

Received Date: January 07, 2017

Accepted Date: January 20, 2017

Published Date: January 28, 2017

Citation: Krishna, N.M., et al. Antimicrobial activity studies from poisonous short nosed tripod fish, Triacanthus biaculeatus (Bloch, 1786) from Visakhapatnam coastal waters, India. (2017) J Med Chem Toxicol 2(1): 24- 27.

DOI: $10.15436 / 2575-808 X .17 .1298$

Keywords: Antimicrobial activity; Pathogens; Short -nosed tripod fish; Visakhapatnam

\section{Introduction}

There is a growing interest in marine natural products or marine secondary metabolites ${ }^{[1]}$. Finding of bioactive compounds from fish have always been of great significant since several decades and it is much more essential to identify inventive natural products which might possess remarkable properties to treat various diseases. Of the natural products isolated from marine organisms ${ }^{[2]}$ only less than $1 \%$ has been examined so far for pharmacological activity ${ }^{[3]}$. Much of studies are warranted to find antimicrobials in the present context of increasing need for novel drugs that can control new illness or resistant strains of microorganisms $\mathrm{s}^{[4]}$. There has been an extensive research showing that bioactive substances were identified and characterized from marine organisms showed promising results to treat human and animal diseases ${ }^{[5]}$. The thirst of natural antimicrobial therapeutics discovery and development is always in

demand for pharmaceutical industries, and its vital significance is to escape the risk of resistance development by pathogenic microorganism ${ }^{[6]}$. This conquest of fish has been accomplished despite the fact that they possess both slower and less developed adaptive immune systems than that of higher vertebrates ${ }^{[7]}$. Due to the aquatic environment, fishes have distinctive anatomical and physical characteristics. Fish live in intimate contact with an environment containing both saprophytic and pathogenic microbes capable of digesting and degrading fish tissues. The slow adaptive immune response of fish makes innate immunity, which is fast acting and temperature independent ${ }^{[7]}$, the predominant system of fish host defense. This innate immune response is essential for the survival of this whole class of animals.

Antimicrobial activity in tissue extracts has been demonstrated in several fish species ${ }^{[8]}$ yet this activity seems to vary from one fish species to the other and can be specific

\section{Copyrights: () 2017 Krishna, N.M. This is an Open access article distributed under the terms of Creative}


towards certain bacteria ${ }^{[8]}$. The secondary metabolites derived from the various marine organisms till date, possess antimicrobial and anticancer properties, while some of them are under clinical trials ${ }^{[10,11]}$. In the present study the muscle extract from short nosed tripod fish $T$. biaculeatus was screened for its in vitro activity against human pathogens.

\section{Materials and Methods}

\section{Sample collection and preparation of extracts}

Triacanthus biaculeatus (Bloch, 1786) samples were collected from the fish landing center of Visakhapatnam (Lat.11 $29^{\prime} \mathrm{N}$; Long. $79^{\circ} 46^{\prime} \mathrm{E}$ ), India during the period of 2014. Freshly collected samples were identified by based on Froese, R., et al., Eds ${ }^{[12]}$ and immediately washed to remove adhered mud and other particles and brought to the laboratory in a frozen condition. The extraction procedure was followed by modified method of Chellaram ${ }^{[13]}$. 50 gms of chopped tissues samples were placed on the solvent methanol and acetone separately in the ratio of 1:3 (w/v) for $24 \mathrm{hrs}$ at normal room temperature, then extracts were filtered by What man filter paper No.1 and the solvents were concentrated by rotary evaporator under reduced pressure and temperature, the resultant residues were stored at $4^{\circ} \mathrm{C}$ for further analysis.

\section{Bacterial Pathogens used}

Antimicrobial activity of $T$. biaculeatus was determined against five bacterial strains viz, Escherichia coli (MTCC-443), Salmonella typhi (MTCC-421), Pseudomonas aeruginosa (MTCC-2295), Vibrio cholera (MTCC-459) and Staphylococcus aureus (MTCC-3160).

\section{In vitro antibacterial activity}

The antibacterial activity was determined by Well Diffusion Methods ${ }^{[14,15]}$. About $25 \mathrm{ml}$ of molten Mueller Hinton agar was poured into a sterile Petri plate. The plates were allowed to solidify, after which 5 different species of pathogenic bacteria namely Escherichia coli, Salmonella typhi, Pseudomonas aeruginosa, Vibrio cholera and Staphylococcus aureus were transferred onto the plates and made lawn culture by using sterile L-rod spreader. After five minutes setting of the bacteria, the wells were made using sterile $5 \mathrm{~mm}$ cork borer. Wells were loaded of extracts prepared by dissolving $1 \mathrm{mg}$ of crude extracts in 1 $\mathrm{ml}$ of distilled water. Streptomycin was used as positive control and negative control was prepared using distilled water. Plates were incubated for $24 \mathrm{hrs}$ at $37^{\circ} \mathrm{C}$. Zone inhibition was recorded in millimeters and three replicates were maintained.

\section{Results and Discussion}

Antimicrobial effect of the T. biaculeatus were tested against, five pathogenic bacteria. The activity was measured in terms of zone of inhibition and expressed in millimeter ( $\mathrm{mm}$ ). The spectrum of antibacterial activity in the fish muscle was shown in given Table-1 and Figure-1.
Table-1: Metholic extract of Triacanthus biaculeatus against water borne pathogens

\begin{tabular}{|l|c|c|}
\hline $\begin{array}{l}\text { Bacterial } \\
\text { Pathogens }\end{array}$ & $\begin{array}{l}\text { Zone of Inhibition } \\
\text { (mm) }\end{array}$ & $\begin{array}{l}\text { Zone of Inhibition } \\
\text { (mm) of Streptomycin }\end{array}$ \\
\hline $\begin{array}{l}\text { Staphylococcus } \\
\text { aureus }\end{array}$ & 1 & 2 \\
\hline Escherichia coli & 3 & 3 \\
\hline Vibrio cholera & 3.8 & 3 \\
\hline $\begin{array}{l}\text { Pseudomonas } \\
\text { aeruginosa }\end{array}$ & 2 & 2 \\
\hline Salmonella typhi & 3 & 1.6 \\
\hline
\end{tabular}

The magnitude of zone of inhibition was $V$. cholera $>$ E. coli and $S$. typhi $>P$. aeruginosa $>S$. aureus. The maximum zone of inhibition was observed against $V$. cholera which is about $3.8 \mathrm{~mm}$ in diameter. Whereas the inhibition zone measured for Streptomycin was $3 \mathrm{~mm}$. This was followed by $E$. coli and $S$. typhi $(3 \mathrm{~mm})$, P. aeruginosa $(2 \mathrm{~mm})$ and $S$. aureus $(1 \mathrm{~mm})$ compared with the streptomycin inhibition zones of $3 \mathrm{~mm}, 1.6 \mathrm{~mm}, 2$ $\mathrm{mm}$ and $2 \mathrm{~mm}$ respectively. The muscle extract of $T$. biaculeatus showed a significant activity with regard to the Gram-positive as well as Gram negative bacteria. The zone of inhibition values of muscle extract of Tripod fish T. biaculeatus were much more than the control (Streptomycin) tested and the inhibitory effect of $T$. biaculeatus against five bacterial pathogens are given in Table-1

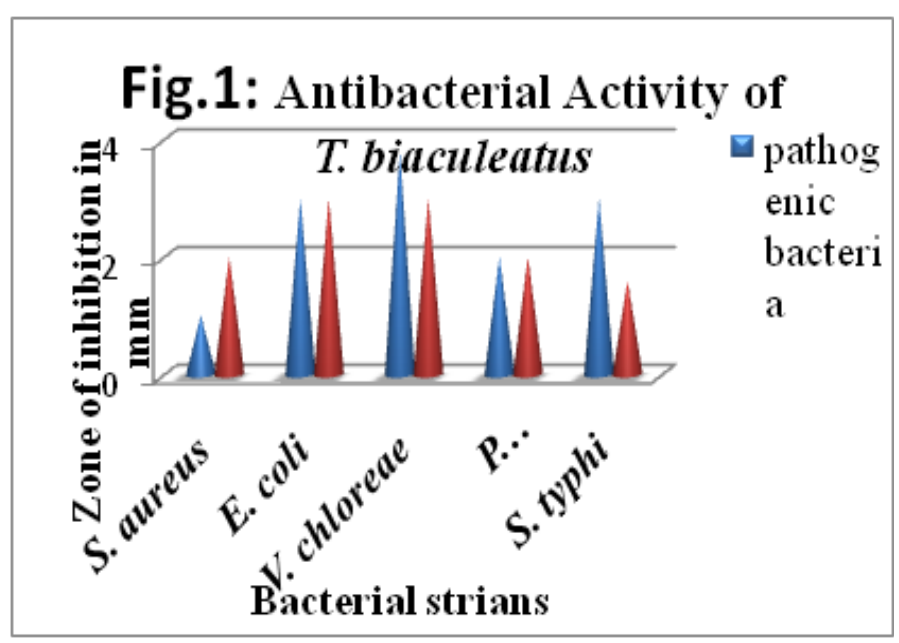

The first attempt to locate antimicrobial activity in marine organisms was initiated around $1950{ }^{\prime} \mathrm{S}^{[16]}$. Since this time, a large number of marine organisms from a wide range of phyla have been screened for antimicrobial activity ${ }^{[17]}$. Many of these organisms have antimicrobial properties, although most of the antibacterial agents that have been isolated from marine sources have not been active enough to complete with classical antimicrobial activity against microorganisms ${ }^{[18]}$.

Fish is the earliest and the largest class vertebrate in marine biota with its innate immune system being considered as the predominant mechanism for host defense ${ }^{[19]}$ which includes excretion of antimicrobial peptides, polypeptides, non-classical complement activation, cytokine release, inflammation and phagocytosis ${ }^{[20,21]}$. Precisely, fishes evolved several innate immune mechanisms to defend microbial infection ${ }^{[19]}$. On the other hand, fishes hold the credit of possessing rich protein 
sources. These marine proteins are not only correlated to the intact proteins, but also to the possibility of generating bioactive peptides $^{[14]}$. In recent years, different toxins derived from marine sources have been identified as having potential antimicrobial activities. Precisely, fishes evolved several innate immune mechanisms to defend microbial infection ${ }^{[19]}$. On the other hand, fishes hold the credit of possessing rich protein sources. These marine proteins are not only correlated to the intact proteins, but also to the possibility of generating bioactive peptides ${ }^{[22]}$. Most of reported antimicrobial peptides typically have strong antimicrobial activity against a wide range of Gram-positive bacteria but very weak or no activity against Gram-negative bacteria, like mitomycin $^{[23]}$.

In the present study, muscle extract of $T$. biaculeatus showed considerable inhibitory activity against Gram-negative bacteria within short span of time. Hence, it is obvious that the secondary metabolites produced from the associated microorganisms could transport into the muscle tissue and hence exploitation of associated microorganisms could solve the supply problem of raw materials i.e., host organisms and hence the biodiversity of marine organisms could be conserved for the future benefits ${ }^{[4]}$. Interesting finding from the antimicrobial sensitivity of associated bacteria must play a role in host defense, and thus constitute a valuable source of immune competent effect or cells for in vitro analyses. However, majority of marine organisms are yet to be screened discover useful antibiotics. Epidermal secretory cells of fishes have been noted to be two types: secreting proteinaceous material and other mucus ${ }^{[24]}$. According to Boman, 1995 and Andreu, D., et al., 1998 ${ }^{[25,26]}$ most of the antimicrobial peptides kill bacteria by a common mechanism, which involves direct electrostatic interactions with negatively charged phospholipids on microbial cell membranes followed by physical disruption and solubilization. Fish contain serum and cellular interferon which possess anti-viral proteins (e.g. $\alpha$-macroglobulin and other $\beta$-globulins) that inhibit the extra cellular proteases secreted by pathogens ${ }^{[27]}$. They added that number of relatively specific lytic molecules, like hydrolase enzymes (Lysozyme, Chinase and Chitobiase) act on bacteria. Fish also contain lectins possess antibacterial and antifungal activities. Several drugs from marine organisms have entered the market as anti-cancer, anti-microbial, anti-tumour, anti-inflammatory, anti-oxidant, cytotoxic, anti-coagulant, immunemodulatory, anti metastatic, fibrinolytic agents and so on, after a series of clinical trials ${ }^{[28-30]}$.

The data of present study indicate that the antibacterial activity of the fish muscle may be due to the presence of the above said substances. The mode of action of muscle extract is yet to be determined but studies have proposed various killing mechanisms for fish derived antimicrobials such as cytoplasmic membrane disruption, pore or channel formation ${ }^{[31]}$ and inhibition of cell wall and nucleic acid synthesis ${ }^{[32,33]}$.

\section{Conclusion}

Based on the assay conducted and surveyed literatures we concluded that the Triacanthus biaculeatus has potential antimicrobial activity of many polar compounds particularly against $V$. chloreae, E.coli and S.typhi. This study is suggesting that many promising compounds which have potential pharmaceutical values from these untapped sources to be evaluated for curing many diseases. T. biaculeatus are underutilized for hu- man usage and they can be explored for other pharmaceutical applications with sustainable conservation.

\section{References}

1. Rana, M., Luesch. H. Marine natural products: a new wave of drugs? (2011) Future Med Chem 3(12): 1475-1489.

2. Rao, D.S., James, D.B., Girijavallabhan, K.G. Biotoxicity in echinoderms. (1985) J Mar Bio 27(1\&2): 88-89.

3. Fusetani, N. Drugs from the sea (2000) Basel Karger 1-5.

4. Williams, G.P., Babu, S., Ravikumar, S., et al. Antimicrobial activity of tissue and associated bacteria from benthic sea anemone Stichodactyla haddoni against microbial pathogens. (2007) J Env Biol 28(4): 789-793.

5. Grabley, S., Thiericke, R. Bioactive Agents from Natural Sources: Trends in Discovery and Application. (1999) Adv Bio Eng Biotech 64: $101-154$.

6. Kang, H.K., Seo, C.H., Park, Y. Marine peptides and their anti-infective activities. (2015) Mar Drugs 13(1): 618-654.

7. Kumaravel, K., Ravichandran, S, Sharmila, F.R, et al. In vitro Antimicrobial Activity of Tissue Extracts of Puffer fish Arothronim maculatus Against Clinical Pathogens. (2011) J Natural Medicines 9(6): 446-449. 8. Austin, B., McIntosh, D. Natural antibacterial compounds on the surface of rainbow trout, Salmo gairdneri Richardson (1988) J Fish Dis 11: 275-277.

9. Noga, M., Magarinos, B., Toranzo, A.E., Sequential pathology of experimental pasteurellosis in Gilthead Sea bream Sparus aurata a light microscopic and electron microscopic study. (1995) Dis Aqua Org 21: 177-186.

10. Schwartsmann, G., Rocha, A.B., Mattei, J., et al. Marine-derived anticancer agents in clinical trials. (2003) Expert Opin Investig Drugs 12(8): 1367-1383.

11. Simmons, T.L., Andrianasolo, E., McPhail, K., et al. Marine natural products as anticancer drugs. (2005) Mol Cancer Ther 4(2): 333-342.

12. Froese, R., Pauly, D (Eds.) FishBase 2000, concepts, design and data sources. (2000) xvii,344p. Los Banos, Laguna, Philippines, ICLARM. 13. Chellaram, C., Mary Elizabeth G., Patterson Edward, J.K. Antibacterial activity of the winged oyster Pteriachinensis (Pterioida: Pteridae). (2004) J Mar Sci 33(4): 369- 372.

14. Perez, C., Pauli, M., Bazerque, P. An antibiotic assay by agar-well diffusion method. (1990) Acta Biol Med Exp 15: 113-115.

15. Chenielle, D., Lois, R., Alison, N., et al. Antibacterial and antifungal analysis of crude extracts from the leaves of Callistemon viminalis. (2009) J Med BioSci 3(1): 1-7.

16. Shaw, P.D., McClure, W.O., Blaricom, G. Antimicrobial activities from marine organisms, In: Webber, H.H \& Ruggieri, G.D. (eds) Fooddrugs from the Sea Proceedings [M]. Washington: (1974) Mar Tech Soc 429-433.

17. Rinehart, K.L., Shaw, P.D, Shield, L.S. et al. Marine natural products as a source of antiviral, antimicrobial and antineoplastic agents. (1981) Pure App Chem 53(4): 795-817.

18. Kumaravel, K., Ravichandan, S., Balasubramanian, K., et al. Antimicrobial effect of five seahorse species from Indian coast. (2010) Br J Pharmacol Toxi 1(2): 62-66.

19. Indumathi, S.M., Manigandan, V., Khora, S.S. Antimicrobial and larvicidal activities of the tissue extracts of oblong blowfish (Takifuguoblongus) from South - East Coast of India. (2016) J Toxic Phar Res 8(5): 312-319.

20. Magnadottir, B. Innate immunity of fish (overview). (2006) J Fish Shellfish Immun 20(2): 137-151.

21. Fernandes, J.M., Smith, V.J. A novel antimicrobial function for a ribosomal peptide from rainbow trout skin. (2002) J Bio chem Bio phys Res Commun 296(1): 167-171.

22. Dai-Hung, N., Thanh Sang, V.O., Isuru Wijesekara., et al. Marine food-derived functional ingredients as potential antioxidants in the food industry: an overview. (2011) Food Res Int 44: 523-529. 
23. Mitta, G., Vandenbulcke, F., Roch, P. Original involvement of antimicrobial peptides in mussel innate immunity. (2000) FEBS Let 486(3): 185-190.

24. Cameron, A.M., Endean, R. Epidermal secretions and the evolution of venom glands in fishes. (1978) Toxic 11(5): 401-410.

25. Boman, H.G. Peptide antibiotics and their role in innate immunity. (1995) Ann Rev Immune 13: 61-92.

26. Andreu, D., Rivas, L. Animal antimicrobial peptides: an overview. (1998) Bio 47(6): 415-433.

27. Alexander, J.B., Ingram, G.A. Non cellular nonspecific defense mechanism of fish. (1992) Ann Rev Fish Dis 2: 249-279.

28. Faulkner, D.J. Marine natural products. (2001) Nat Prod Rep 18(1): $1-49$.

29. Boopathy, N.S., Kathiresan, K. Anticancer Drugs from Marine Flora: An Overview. (2010) J Oncol 2010: 1-18.

30. Montaser, R., Luesch, H. Marine natural products: a new wave of drugs? (2011) Future Med Chem 3(12): 1475-1489.

31. Syvitski, R., Burton, I., Mattatall, N.R., et al. Structural characterization of the antimicrobial peptide pleurocidin from Winter flounder. (2005) Bio Chem 44(19): 7282-7293.

32. Patrzykat, A., Friedrich, C.L., Zhang, L., et al., Sub lethal concentrations of pleurocidin-derived antimicrobial peptides inhibit macromolecular synthesis in Escherichia coli. (2002) Anti-microbial Agents Chemo 46(3): 605-614.

33. Brogden, K.A. Antimicrobial peptides: pore formers or metabolic inhibitors in bacteria? (2005) Nat Rev Micro Bio 3(3): 238-250.

Ommega Online Publisher

Journal of Medicinal Chemistry \& Toxicology

Short Title : J Med Chem Toxicol
E-mail: medchemtoxic@ommegaonline.org website: www.ommegaonline.org 